\title{
在日外国人の人口学的特徵と児童福祉の課題
}

\author{
北野 尚美 ${ }^{1,2,3}$, 李 錦純 $^{4}$, 中村 安秀 $^{5}$ \\ ' 和歌山県立医科大学地域・国際貢献推進本部地域医療支援センター \\ 2 和歌山県立医科大学医学部公衆衛生学講座 \\ ${ }^{3}$ 大阪大学大学院人間科学研究科 \\ 4 関西医科大学看護学部・看護学研究科 \\ 5 甲南女子大学看護リハビリテーション学部
}

\section{Demographic Characteristics of Foreign Residents in Japan; Child Maltreatment and Language Problems in Child Protection Services}

\author{
Naomi KITANO ${ }^{1,2,3}$, Kumsun LEE ${ }^{4}$ and Yasuhide NAKAMURA \\ ${ }^{1}$ Research Center for Community Medicine, Wakayama Medical University \\ ${ }^{2}$ Department of Public Health, School of Medicine, Wakayama Medical University \\ ${ }^{3}$ Graduate School of Human Sciences, Osaka University \\ ${ }^{4}$ Faculty of Nursing, Kansai Medical University \\ ${ }^{5}$ School of Nursing and Rehabilitation, Konan Women's University
}

\begin{abstract}
In this study, we examined the changes in the demographic characteristics of foreign residents in Japan (FRJ) and the current status of FRJ from a global health perspective. We also considered child maltreatment that occurred in FRJ families and language problems in child welfare. Japan's official statistics in the end of 2017 indicated that there were more than $\mathbf{2 . 5 6}$ million FRJ from over 190 countries. This population was diverse with heterogeneous characteristics, such as age structure, dwelling place, marital status, and childbirth. At the end of 2017, there were 219,982 FRJ children aged 0-14 of various nationalities, including Chinese, Brazilian, South Korean, North Korean, Filipino, Vietnamese, Peruvian, Nepalese, and Indian. In 2010, we conducted our first survey of child maltreatment in FRJ families, targeting 219 child protection centers across Japan. Between April 2007 and August 2010, 1,639 child maltreatment cases were reported from $56 \%$ of these centers. Details of 1,111 cases were collected and descriptive analyses were conducted. The male-to-female ratio was 0.88 and the median age was 8 years: however, the age distribution showed that females were significantly older than males $(P<0.01)$. The proportions of physical abuse, child neglect, emotional abuse, and sexual abuse were $38 \%, 33 \%, 21 \%$, and $7 \%$, respectively. Native language problems created numerous challenges and required a large amount of effort from child welfare practitioners. However, most solutions to identified problems were still at the beginning stage and some were found to be ineffective. More interdisciplinary and integrated researches are needed targeting child welfare of FRJ. An ethical framework for good counseling practices should be developed.
\end{abstract}

Key words： foreign residents in Japan（在日外国人)， native language（母語）， child maltreatment（児童虐 待／マルトリートメント), child protection (子ども保護), descriptive epidemiology（記述疫学）

受付 2018 年 8 月 24 日, 受理 2018 年 12 月 6 日

Reprint requests to: Naomi KITANO

Research Centre for Community Medicine and Department of Public Health, School of Medicine, Wakayama Medical University, Kimiidera 811-1, Wakayama 641-8509, Japan Tel: +81(73)441-0845, Fax: +81(73)441-0846

E-mail: naomiuk@wakayama-med.ac.jp

\section{1. 緒言（はじめに）}

わが国の児童虐待について公表されている統計值は, 「児童相談所に打ける児童虐待相談対応件数」(1) で, 社会福祉行政業務報告に基づいて児童相談所（以下，児 
相）の全数調査により得られた数值である。相談対応件 数は, 養護相談, 障害相談, 非行相談, 育成相談, その 他の相談に分類して数值が公表され, 児童虐待は養護相 談に含まれる。相談対応件数とは, 児相が相談を受けて 援助方針会議の結果により指導や措置等を行った件数 で，「児童虐待の防止等に関する法律（平成 12 年法律第 82 号)」(以下，児童虐待防止法）が制定された 1990 年 度以降の数值が存在する。児童虐待相談対応件数は右肩 上がりで，平成 29 年度は 133,778 件（速報值）で，そ の内訳は，心理的虐待 $(54.0 \%)$, 身体的虐待 $(24.8 \%)$, ネグレクト $(20.0 \%)$, 性的虐待 $(1.2 \%)$ であった。なお， 日本で児童虐待防止対策に和忊る児童虐待の定義は, 児 童虐待防止法 (超党派による議員立法で1990年 5 月成立, 同年 11 月施行）の第 2 条によって, 初めて前述の 4 種 類が定義された。第一回「児童虐待の防止等に関する法 律改正」(2004年 10 月施行) によって, 第 1 条の目的 の見直し(児童虐待は著しい人権侵害であることを明記) を踏まえて, 児童虐待の定義の見直し（保護者以外の同 居人による児童虐待, ドメスティック・バイオレンス) と通告義務の拡大（児童虐待を受けたと思われる児童） などの改正に合わせて，児童福祉法の一部改正が成され た。その後の第二回「児童虐待の防止等に関する法律」 の一部改正 (2007年 6 月成立) によって, 第 1 条の目 的に, 児童の権利利益の擁護に資することが明記され， 児相の権限強化がなされ，この改正に合わせて児童福祉 法も一部改正（2008 年 4 月施行）された。

児相は児童福祉法第 12 条の規定によって都道府県ま たは政令指定都市が設置する機関で，最近では「児童福 祉法等の一部を改正する法律（平成 28 年法律第 63 号)」 （2016 年 5 月成立・ 6 月公布）によって，児相について， 専門職の配置充実の促進や権限強化が成され, 設置自治 体が拡大された。しかしながら，児相の設置基準には， 出生数や年少人口など子ぞも数に関わる数值は盛り込ま れていない。また，全国児童相談所長会では全国の児相 に対して現状調査が年数回実施されるが，児相の管轄区 域に関してなど調查研究に活用可能な情報の公表はない。

2000 年度に実施さ扎た家庭内児童虐待の全国調査 (厚 生労働科学研究 主任研究者: 小林 登) (2) 飞よって, 子ぞも虐待の年間新規発生数は $35,000,18$ 歳未満人口 1,000 人当たり $1.54(0.15 \%)$ と推計された。この分担 研究 (分担研究者: 小池通夫) として, 特定の県内全域 で子どもに関わるすべての施設を対象に悉皆調查が実施 された。その結果をもとに算出された年間新規発生の推 定は, 18 歳未満人口 1,000 人対 $1.52 \sim 2.13$ であった (3)。 しかしながら, 当時の調査は, その項目に国籍（出身地） を含まなかった。公表されてある「子ども虐待による死 亡事例等の検証結果等について」第 $1 \sim 14$ 次報告 (4) を参照することで，虐待死または重傷事例の概要はわか るが, ここでも国籍（出身地）の情報はなく, 在日外国 人の親をもつ子ぞもに発生した児童虐待に関しては不明 である。
近年，児童福祉法等の一部を改正する法律（施行期日 2017 年 4 月 1 日）の第 1 条「全て児童は，児童の権利 に関する条約の精神にのっとり, 適切浿育されること, その生活を保障されること, 愛され, 保護されること, その心身の健やかな成長及び発達並びにその自立が図ら 孔ることその他の福祉を等しく保障される権利を有す る。」によって，児童の福祉を保障するための理念が明 確化された。その対象は，日本に在住するすべての子ぞ もであり, 支援対象には在日外国人の親子・家族が含ま れる。しかしながら，在日外国人の親をもつ子どもに発 生した児童虐待に関する実態把握が不十分である。

母子の健康水準向上のための国民運動計画である「健 やか親子 21 (第 2 次)」では，10 年後に目指寸姿を「す べての子ぞもが健やかに育つ社会」として，すべての国 民が地域や家庭環境等の違いにかかわらず，同じ水準の 母子保健サービスが受けられることを目指している(5)。 「娃娠期からの児童虐待防止対策」はその重点課題であ り,「切机目ない妊産婦・乳幼児への保健対策」は基盤 課題の 1 つ位置づけられた。

近年，『子ぞも虐待による死亡事例等の検証結果等に ついて (第 8 次報告)』を踏まえた対応について」(平成 24 年 7 月 26 日付雇児総発 0726 第 1 号, 雇児母発 0726 第 1 号厚生労働省雇用均等 - 児童家庭局総務課長, 母子 保健課長通知）に関して, 具体的な留意事項として「養 育支援を特に必要とする家庭の把握及び支援について」 (平成 24 年 11 月 30 日付雇児総発 1130 第 1 号, 雇児母 発 1130 第 1 号）飞扔いて, 市町村が中心となって特定 妊婦（児童福祉法第 6 条の 3 第 5 項に定義された，養育 上の公的支援を妊娠中から要するような環境にある妊 婦)の把握及び情報収集が求められた。この別添として, 出入 (帰) 国記録等に係る照会に当たっての留意事項 (平 成 24 年 6 月付村法務省入国管理局）が示され, 照会書 への国籍の記載等が示されている。市町村においては, 妊娠届出時に, 母子保健法施行規則に規定されてある届 出事項（届出年月日, 氏名, 年齢, 職業, 居住地, 他) に限らず，望んだ妊娠か，支援者の存在など児童虐待予 防のための情報収集がなされている(6)。しかしながら， 2017 年の調査結果で, 本人やパートナーの国籍 (出身地) の把握は，ごく一部の自治体に限られていた（6)。

一方, 児童福祉法を根拠法とする乳児家庭全戸訪問事 業はポピュレーション・アプローチの施策で，2009年 度に厚生労㗢省に上って児童虐待の一次予防を目的とし て導入された。しかしながら，外国人の親と子どもを対 象としたアプローチに関して, 市町村向けの手引き書な ど指針となるるのは示されておらず，個別のケースに手 探り状態で対応している現状がある (7)。母子保健事業 や児童福祉事業の実施にあたって, 国籍（出身地）や文 化・生活様式など家族の背景への理解は重要な要素であ り，事前の情報収集と的確な準備は欠かせない $(8,9)$ 。 在日外国人家庭に扔いては言語や生活の様式・習慣が異 なるだけでなく，日本の地域社会において保健医療福祉 
などの社会資源の活用が困難な環境にあることが少なく ない $(10,11)$ 。加えて, 国際結婚カップルでは, 経済面 の不安定 (12) や，ドメスティック・バイオレンスの問 題 (13), 父母間で生育環境が異なったことに由来する 子どもに対する認識やしつけの手法の違いなど妊娠・出 産・育児の過程で顕在化してくる問題もある $(8,9,14)$ 。

児相の相談業務では，児童福祉の専門的な知識やスキ ルと経験を必要とするため, 通常の母語での対応に颃い ても不十分なコミュニケーションとなって相互に理解が 進まないことも珍しくない。福祉の現場での言語の課題 は重大である $(11,15,16)$ 。不自由な言語は相談者の不 利益に直結する恐孔があり, 結果として不十分な対応の 原因となり得る。相談者が日本語の語学能力を十分に兼 ね備えている場合であっても, 生まれ育った国（地域） や環境が異なれば生活の習慣や様式から, 性別役割分担 などジェンダーや子育てに関する知識や認識, さらに感 情表現なども異なる。そのため, 児相の担当者が予測の 範囲に収まらない相談内容に出くわして対応に難渋し, 熱心な対応にも関わらず意思疎通の困難が発生すること が予測される。

わが国では，国際結婚カップルや外国人を親にもつ子 ぞもの数が増加傾向にあり, 在日外国人の年少人口は約 22 万人で, その国籍 (出身地) は中国やブラジル, 韓国・ 朝鮮, フィリピン, ベトナム, ペルー, ネパール, イン ドなど多岐にわたっている。在日外国人に関する人口動 態統計をはじめとした基本データは，2008 年より運用 されている政府統計のポータルサイト「政府統計の総合 空口（e-Stat）」(17）など近年整備されつつある。しか しながら, 在日外国人家庭の览童虐待に関する既存の統 計值は存在せず，児相に打ける外国人からの相談への対 応の現状に関しても十分に実態が把握されていない現状 にある。そこで, 本稿ではグローバル・ヘルスの視点 $(18$, 19）から, まず, 在日外国人の人口学的特徵の推移と現 状および人口統計に関わる課題について, 著者らが実施 した資料調査の結果をもとに概説した。次に，全国の児 相を対象とした悉皆的な調査結果 (20) をもとに, 在日 外国人の親をもつ子どもに発生した家庭内児童虐待につ いて疫学的記述を行った。加えて, 日本に扣ける国内の 国際化への対応の一例として, 福祉等行政サービスに抒 ける多言語の問題について課題を提示した。

\section{2. 在日外国人の人口統計と国籍（出身地）別 人口構成の特徵}

わが国で起きている「内なる国際化」について知るに は，公表されている資料や指標に基づいた，在日外国人 の人口動態統計の特徵を知る必要がある。

ここで「在留外国人」について概説する。外国人登録 法の廃止打よび住民基本台帳法改正により，在留外国人 とは，「中長期在留者拈よび特別永住者」を指す。中長 期在留者とは，出入国管理及び難民認定法上の在留資格
をもって日本に中長期間在留する外国人で，具体的には 以下の(1)から(6)までのいずれにもあてはまらない者であ る（1）「3 月」以下の在留期間が決定された者，(2)「短 期滞在」の在留資格が決定された者, (3)「外交」又は「公 用」の在留資格が決定された者, (4) (1)から (3)までに準 じるものとして法務省令で定める者（「特定活動」の在留 資格が決定された，亜東関係協会の本邦の事務所若しく は駐日パレスチナ総代表部の職員又はその家族)，(5) 特 別永住者, (6) 在留資格を有しない者)。

本稿で，在日外国人とは，中長期在留者执よび特別永 住者の在留資格を有する者を指す。関連用語として,オー ルドカマー（旧来外国人）とニューカマー（新来外国人) がある。オールドカマーは, 旧植民地時代より引き続き 日本に定住・永住している外国人とその子孫を指し, 主 に在日韓国・朝鮮人と台湾人である。ニューカマーは, 1980 年代後半以降に来日し, 定住した外国人一般を指 す。在日外国人の人口に関して, 本稿では在留外国人統 計（21）を用いた。

まず在日外国人の人口の動向抒よび，在日外国人の国 籍 (出身地) 別人口構成の特徵に関して概観する。

\section{1）在日外国人の人口統計に関する既存資料について}

在日外国人の人口についての日本の調査は，戦後では 国勢調査と 1947 年から始まった法務省入国管理局調査 がある。法務省入国管理局による在留外国人統計の第 1 回の発刊は 1960 年であり, 外国人登録に基づいて, 毎 年国籍別・在留資格別・年齢別人口について集計・公表 されている。人口静態調査の代表である国勢調査では, 日本国内に暮らすすべての人が調査対象であり，外国人 住民も調查対象に含まれる。通常は出生数や死亡数は人 口動態統計で把握される。しかしながら, 在日外国人の 家族構成や就労状況に関する統計データは, 国勢調査で の久集計公表されている。

日本政府が公表する人口動態統計 (22) は, 厚生労働 省大臣官房統計情報部より，1899 年（明治 32 年）から 実施・発刊されている基本的な人口統計の 1 つであり, 在日外国人の死亡統計括よび出生や婚姻に関しては, 中・ 下巻扎よび「保管・付録」に分散してまとめられている。 国連の「人口動態統計に関する原則と報告」に扣いて当 該国内で発生した事象はすべて集計対象とする原則があ ること, 外国人の人口動態事象の発生状況が日本人と異 なっていること，1990 年より在日外国人人口が日本の 総人口の $1 \%$ を越える潘ど顕著な増加があったことか ら, 2002 年度に初めて, 人口動態統計特殊報告として「日 本に打ける人口動態一外国人を含む人口動態統計一」が まとめられた $(23)$ 。以後， 5 年後の 2007 年度に第 2 回 目 (24), さらにその 7 年後の 2014 年に第 3 回目の発刊 があった。しかしながら，これらは原本に記載された統 計資料すべてを網羅したものではない。各年度の国籍(出 身地）別人口に関しては法務省の在留外国人統計に記載 されている。 


\section{2）在日外国人の人口の動向について}

\section{（1）在日外国人の総数および推移}

図 1 亿, 日本に拈ける在留外国人の人口推移（19482017 年）を示した。2017 年 6 月に抢ける在留外国人統 計 $(25)$ にると在留外国人数は $2,471,458$ 人であり，日 本人総人口 $(2017$ 年 6 月 1 日現在, 確定值) (26) 飞占 める在留外国人割合は $1.95 \%$ で，女性が $1,286,562$ 人 $(52.1 \%)$ ，男性が $1,184,896$ 人 $(47.9 \%)$ で，女性の方が やや多い構成となっている。2017 年 12 月の在留外国人 統計 $(25)$ で, 在留外国人数は $2,561,848$ 人で過去最高と なり, 前年度末に比べ $7.5 \%$ 増であった。都道府県別では, 長崎県を除く 46 都道府県で在留外国人数は前年末を上 回り，東京都の 537,502 人が最多で全国の $21 \%$ を占め, 愛知県, 大阪府, 神奈川県, 埼玉県の順で, 上位 5 都府 県で全体の $53.9 \%$ を占めた $(25)$ 。

（2）在日外国人の国籍（出身地）別人口

在留外国人の国籍（出身地）は190 か国を上回り，そ の内訳はアジア出身が約 205 万人, 南米出身が約 25 万 人である $(25)$ 。

2017 年 6 月に打ける在日外国人の国籍（出身地）別 人口割合は，中国 711,486 人 $(28.8 \%)$ が最多であり, 韓国・朝鮮 484,627 人 $(19.6 \%)$, フィリピン 251,934 人 (10.2\%) の順に続く (25)。中国は 1970 年代以降増加し 続けて扣り, 過去 10 年間で 10 万人の増加となってい る。旧植民地時代に移住した在日韓国・朝鮮人は戦後 より一貫して 60 万人を超える最大の人口集団であった が 1991 年をピークとして人口減少に転じ, 2007 年末 に初めて「中国」人口が「韓国・朝鮮」人口を上回っ た。フィリピンは, 10 年前に 20 万人を超え, この 10 年間で 5 万人の増加があり, 2017 年 6 月現在第 3 位の 人口集団となっている。近年では, ベトナムと, ネパー
ル，インドネシアの増加が顕著であり，2017 年 12 月の 最新データでは，ベトナムはフィリピンを抜いて 3 位と なった。

\section{3）在日外国人の子どもに関する人口学的特徵 (1) 国際結婚の動向}

図 2 に, わが国に拈ける国際結婚の年次推移 (19652016 年）を示した。日本人と外国人の婚姻件数の年次 推移を見ると，1965 年に拈いては，夫妻の一方が外国 人の婚姻数は 4,156 件だったが, 1983 年に 1 万件を超光, 1999 年には 3 万件，そして 2006 年には約 4 万 5,000 件 とピークに達した。以降は減少が続き, 2016 年現在 21,180 件となっている。

2016 年に打ける, 夫・外国人の国籍別婚姻件数をみ ると, 韓国・朝鮮が 1,627 件 $(25.7 \%)$ と最も多く, 米国, 中国と続く。妻・外国人の国籍別婚姻件数は, 中国が 5,526 件 (37.2\%) で最多であり, フィリピン，韓国・朝鮮の 順であった。

（2）日本における外国人の出生数と在日外国人母によ

\section{る若年出産}

図 3 に，日本に打汀「父母の一方が外国人」の出生 数拈よび,「父母ともに外国人」の出生数の年次推移 （1987-2016 年／1987-2013 年）を示した。外国人の親 をもつ子ぞもには，両親とも外国人，父母どちらか一方 が外国人のケースがある。両親のどちらかが日本人であ る場合には，子どもは日本国籍を取得できる。父母のど ちらか一方が外国人の出生数は, 1987 年より経年的に 増加し，2007 年をピークに微減に転じている。2015 年 以降, 母・外国人 / 父 -日本人の出生数を父・外国人 母・日本人の出生数が上回り，2016 年には両者あわせ て 19,118 人となっている。父母ともに外国人の出生数は,

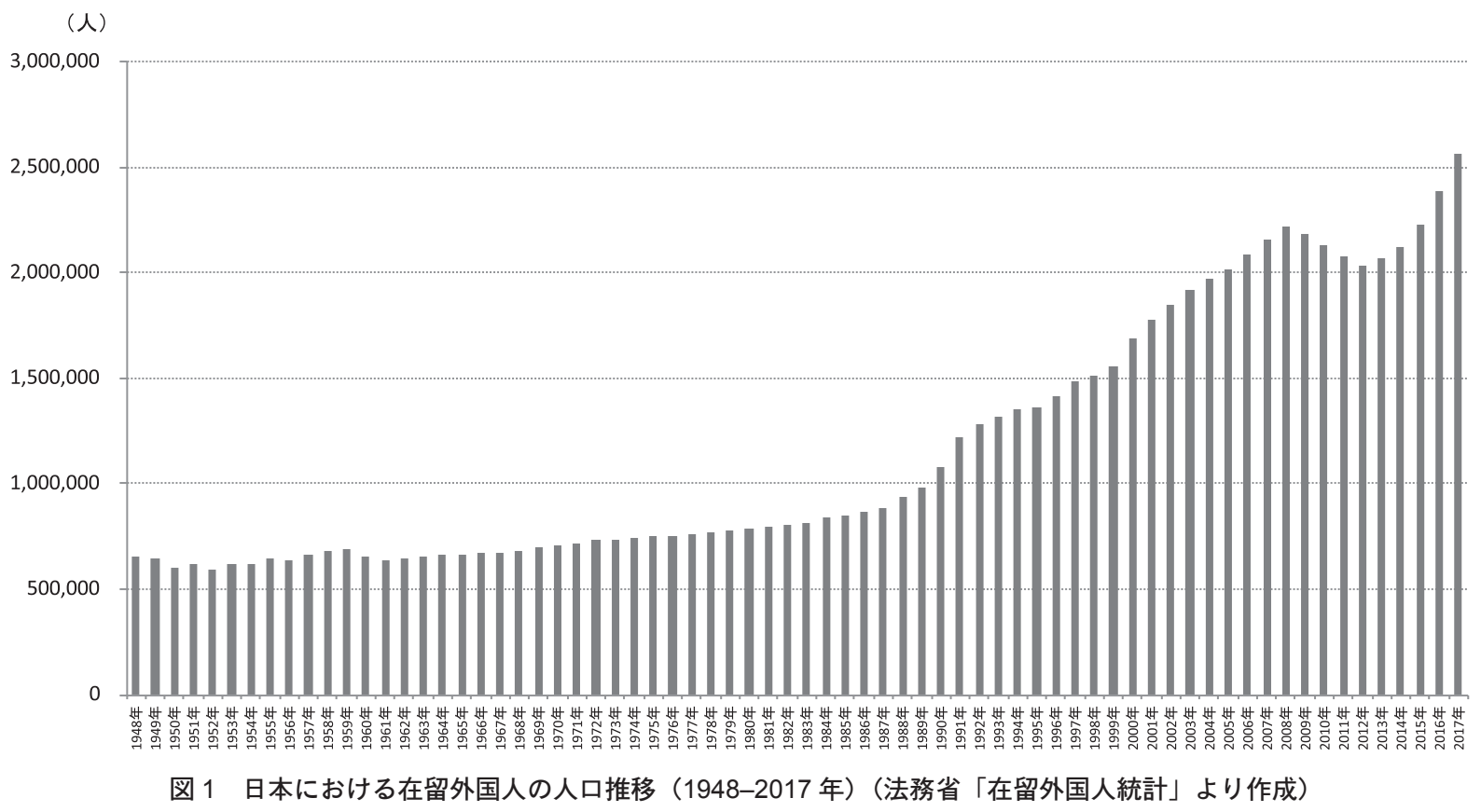




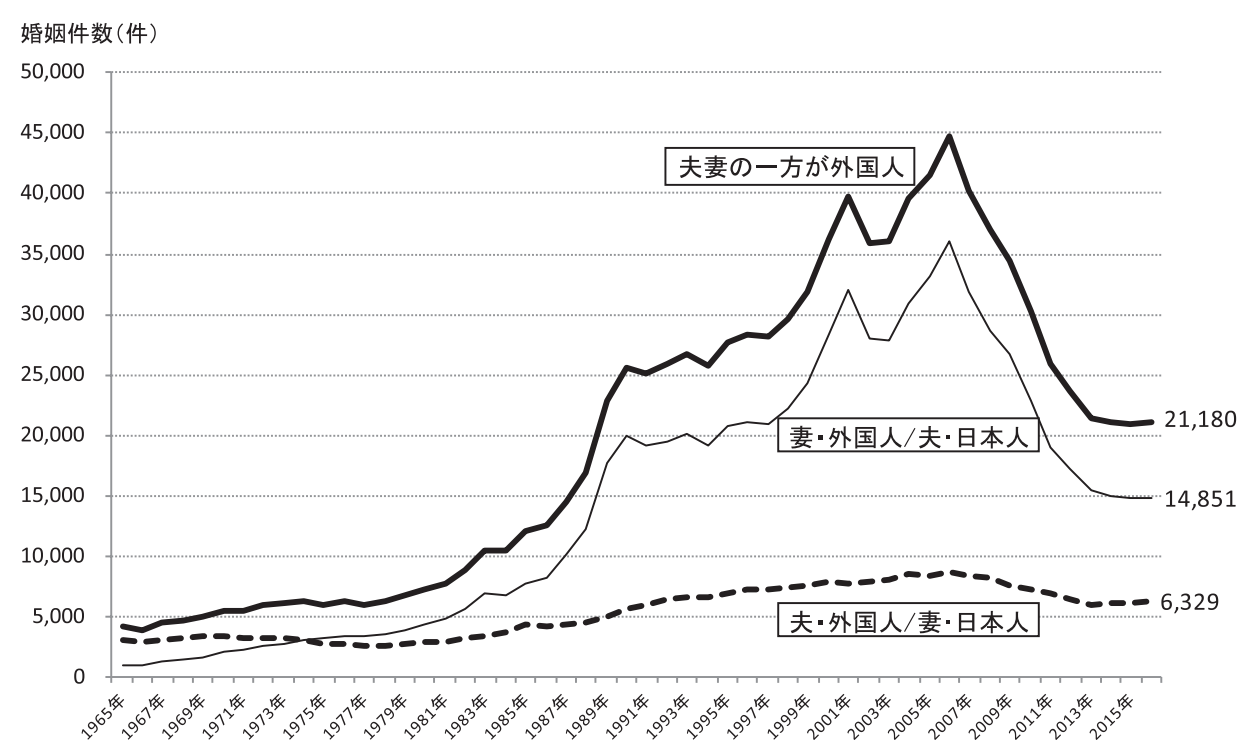

図 2 日本における国際結婚の年次推移（1965-2016 年）(厚生労働省「人口動態統計」より作成）

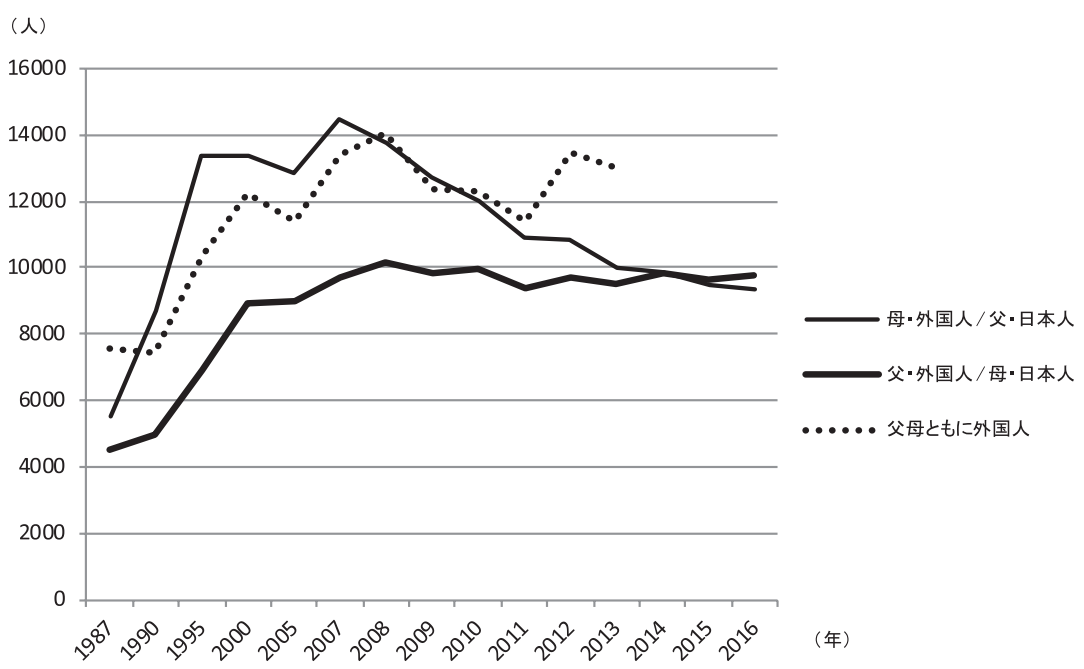

図 3 日本における父母の一方が外国人／父母ともに外国人の出生数の年次推移（1987-2016 年／1987-2013 年） *嫡出子数を示す

2008 年の 14,076 人をピークに微増減で推移し， 2013 年 には 12,997 人となっている。

2016 年に打汀る父母の国籍（出身地）別出生数では, 母・外国人/父・日本人の場合は, 中国, フィリピン, ブラジルの順に多かった。父・外国人/母・日本人の場 合，韓国・朝鮮，米国の順になっている。

ところで，若年出産は，児童虐待の危険因子として行 政による積極的な介入の対象である。在日外国人が関わ る若年妊娠・出産については, 厚生労働省人口動態統計 による母の国籍・母の年齢 (5 歳階級) 別出生数の統計 が参考となる。在日外国人母による若年出産について, その国籍 (出身地) 別ではブラジルとフィリピンで 6 割 を占めることがわかっている。具体的な数值は, 人口動 態統計（2009年）によると, 在日外国人母による出生 総数 12,349 人のらち母年齢 20 歳未満は 373 人 $(3.0 \%)$ で,
その内訳はブラジル 172 人 $(46.1 \%)$, フィリピン 80 人 $(21.4 \%)$ ，ペルー 30 人 $(8.0 \%)$ であった。最新の人口 動態統計（2016 年）によると, 在日外国人母による出 生総数は 17,049 人と増加を認め, 母年齢 20 歳未満は $279(1.6 \%)$ で，その内訳はブラジル 86 人 (30.8\%), フィリピン 83 人 $(29.7 \%)$, 中国 19 人 $(6.8 \%)$, ペルー 14 人 $(5.0 \%)$ であった $(27)$ 。

（3）在日外国人の年少人口における国籍（出身地）別 人口数および割合

表 1 に, 2009 年と 2017 年の在留外国人人口統計から 作成した在日外国人の年少人口の国籍（出身地）別・男 女別の人口分布を 5 歳階級で示した。特にニューカマー で年少人口の割合が高い。図 4 に，2017 年 12 月の 0 〜 14 歳の年少人口に打ける, 国籍（出身地）別人口括よ び割合を示した。年少人口総数に占める割合は, 中国が 
日衛誌 (Jpn. J. Hyg.) 第 74 巻 2019 年

表 1 在日外国人の年少人口における国籍（出身地）別・男女別人口および割合（法務省「在留外国人統計」より作成） 2009 年 12 月現在

\begin{tabular}{|c|c|c|c|c|c|c|c|c|c|c|c|c|}
\hline \multirow{2}{*}{ 順位 } & \multirow{2}{*}{$\begin{array}{c}\text { 国籍 } \\
\text { (出身地) }\end{array}$} & \multicolumn{3}{|c|}{ 総数 } & \multicolumn{2}{|c|}{$0 \sim 4$ 歳 } & \multicolumn{2}{|c|}{$5 \sim 9$ 歳 } & \multicolumn{2}{|c|}{$10 \sim 14$ 歳 } & \multirow{2}{*}{$\begin{array}{l}0 \sim 14 \text { 歳 } \\
\text { 総数 }\end{array}$} & \multirow{2}{*}{$\begin{array}{l}\text { 総数に占める } \\
0 \sim 14 \text { 歳人口 } \\
\text { の割合 }(\%)\end{array}$} \\
\hline & & & 男 & 女 & 男 & 女 & 男 & 女 & 男 & 女 & & \\
\hline 1 & 中国 & 680,518 & 285,548 & 394,970 & 8,982 & 8,486 & 6,529 & 6,098 & 6,732 & 6,344 & 43,171 & 6.3 \\
\hline 2 & 韓国・朝鮮 & 578,495 & 264,296 & 314,199 & 5,578 & 5,421 & 6,784 & 6,391 & 8,341 & 7,921 & 40,436 & 7.0 \\
\hline 3 & ブラジル & 267,456 & 145,292 & 122,164 & 7,590 & 7,140 & 8,372 & 7,658 & 7,575 & 7,188 & 45,523 & 17.0 \\
\hline 4 & フィリピン & 211,716 & 47,204 & 164,512 & 3,103 & 3,033 & 3,312 & 3,266 & 3,420 & 3,742 & 19,876 & 9.4 \\
\hline 5 & ペルー & 57,464 & 30,336 & 27,128 & 1,787 & 1,708 & 1,902 & 1,907 & 1,992 & 1,884 & 11,180 & 19.5 \\
\hline 6 & 米国 & 52,149 & 34,415 & 17,734 & 700 & 761 & 823 & 801 & 701 & 688 & 4,474 & 8.6 \\
\hline 7 & タイ & 42,686 & 11,192 & 31,494 & 306 & 265 & 363 & 365 & 522 & 542 & 2,363 & 5.5 \\
\hline 8 & ベトナム & 41,000 & 22,439 & 18,561 & 898 & 887 & 712 & 648 & 691 & 678 & 4,514 & 11.0 \\
\hline 9 & インドネシア & 25,546 & 16,987 & 8,559 & 424 & 413 & 301 & 304 & 162 & 171 & 1,775 & 6.9 \\
\hline 10 & インド & 22,858 & 15,952 & 6,906 & 846 & 840 & 494 & 470 & 253 & 239 & 3,142 & 13.7 \\
\hline & その他 & 206,233 & 131,818 & 74,415 & 4,398 & 4,265 & 3,385 & 3,188 & 2,552 & 2,404 & 20,192 & 9.8 \\
\hline
\end{tabular}

2017 年 12 月現在

\begin{tabular}{|c|c|c|c|c|c|c|c|c|c|c|c|c|}
\hline \multirow{2}{*}{ 順位 } & \multirow{2}{*}{$\begin{array}{c}\text { 国籍 } \\
\text { (出身地) }\end{array}$} & \multicolumn{3}{|c|}{ 総数 } & \multicolumn{2}{|c|}{$0 \sim 4$ 歳 } & \multicolumn{2}{|c|}{$5 \sim 9$ 歳 } & \multicolumn{2}{|c|}{$10 \sim 14$ 歳 } & \multirow{2}{*}{$\begin{array}{l}0 \sim 14 \text { 歳 } \\
\text { 総数 }\end{array}$} & \multirow{2}{*}{$\begin{array}{c}\text { 総数に占める } \\
0 \sim 14 \text { 歳人口 } \\
\text { の割合 }(\%)\end{array}$} \\
\hline & & & 男 & 女 & 男 & 女 & 男 & 女 & 男 & 女 & & \\
\hline 1 & 中国 & 730,890 & 322,842 & 408,048 & 17,679 & 16,416 & 13,068 & 12,144 & 8,128 & 7,708 & 75,143 & 10.3 \\
\hline 2 & 韓国・朝鮮 & 481,522 & 222,517 & 259,005 & 3,558 & 3,360 & 4,432 & 4,230 & 4,833 & 4,672 & 25,085 & 5.2 \\
\hline 3 & ベトナム & 262,405 & 147,376 & 115,029 & 2,824 & 2,579 & 1,505 & 1,367 & 903 & 804 & 9,982 & 3.8 \\
\hline 4 & フィリピン & 260,553 & 74,735 & 185,818 & 3,863 & 3,808 & 4,043 & 3,997 & 4,307 & 4,277 & 24,295 & 9.3 \\
\hline 5 & ブラジル & 191,362 & 104,109 & 87,253 & 4,980 & 4,764 & 5,881 & 5,486 & 5,644 & 5,191 & 31,946 & 16.7 \\
\hline 6 & ネパール & 80,038 & 49,276 & 30,762 & 1,532 & 1,336 & 641 & 580 & 649 & 520 & 5,258 & 6.6 \\
\hline 7 & 台湾 & 56,724 & 18,051 & 38,673 & 370 & 346 & 280 & 262 & 247 & 225 & 1,730 & 3.0 \\
\hline 8 & 米国 & 55,713 & 36,958 & 18,755 & 687 & 643 & 688 & 678 & 567 & 597 & 3,860 & 6.9 \\
\hline 9 & タイ & 50,179 & 14,037 & 36,142 & 245 & 243 & 253 & 255 & 271 & 273 & 1,540 & 3.1 \\
\hline 10 & インドネシア & 49,982 & 33,843 & 16,139 & 664 & 681 & 430 & 455 & 310 & 231 & 2,771 & 5.5 \\
\hline 11 & ペルー & 47,972 & 25,056 & 22,916 & 1,173 & 1,105 & 1,431 & 1,335 & 1,563 & 1,516 & 8,123 & 16.9 \\
\hline 12 & インド & 31,689 & 21,870 & 9,819 & 1,061 & 1,098 & 855 & 839 & 470 & 471 & 4,794 & 15.1 \\
\hline & その他 & 262,819 & 163,153 & 99,666 & 5,608 & 5,484 & 4,495 & 4,003 & 3,009 & 2,856 & 25,455 & 9.7 \\
\hline
\end{tabular}

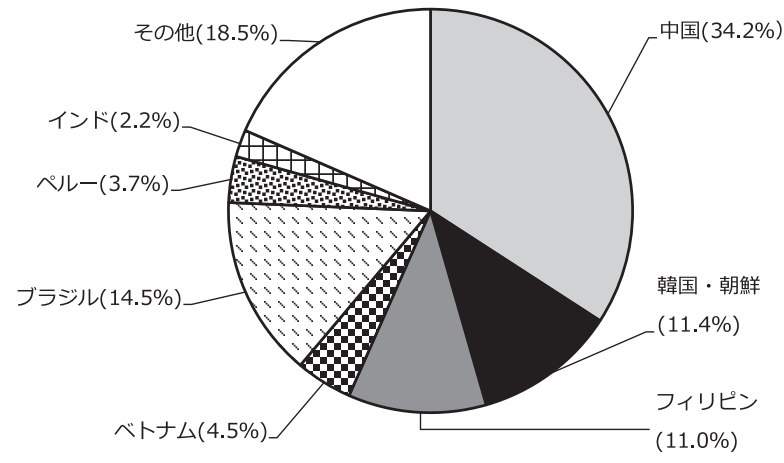

図 4 在日外国人の国籍 (出身地) 別·0 14 歳人口の割合 $(2017$ 年 12 月現在）（法務省「在留外国人統計」より作成）

75,143 人 $(34.2 \%)$ と最多であり，ブラジル 31,946 人 $(14.5 \%)$ ，韓国・朝鮮 25,085 人 $(11.4 \%)$ の順であった。 在日外国人人口最大の構成比を占める中国は, 年齢層 では $20 \sim 29$ 歳人口が最多で 234,527 人 (32.1\%) であっ たのに対し，第 2 位の構成比を占める韓国・朝鮮は 65
歳以上の老年人口が $123,569(25.7 \%)$ であるなど，国 籍（出身地）別に年齢構成上で異なる人口学的特徵が明 らかである。

\section{3. 在日外国人の児童虐待に関する基礎的資料と その限界}

\section{1）新聞報道された在日外国人が関わった児童虐待関連 の記事}

日本に打いて児童虐待防止法が施行された 1990 年以 降の 20 年間（1990-2009年）について，在日外国人が 関わった児童虐待関連記事を調査した結果を示す。著者 らが 2010 年度に, BIGLOBE ビジネスデータ・データベー スを用いて，全国紙 4 紙と地方紙 28 紙に掲載された記 事を対象に，検索語を「在日外国人／児童／虐待」とし て調べたところ 40 件がヒットした。在日外国人の親に よる虐待事例は全国に散見して打り, 虐待死の背景には, 不法滞在や不就学, 父親不在, 貧困など深刻な日常生活 の問題があった。また，外国人親による児童虐待の相談 
表 2 年少人口における国籍（出身地）別・年次別の不慮の事故による死亡数（厚生労働省「人口動態統計」より作成）

\begin{tabular}{|c|c|c|c|c|c|c|c|c|c|c|c|}
\hline 西暦 & 性別 & 総 数 & 韓国・朝鮮 & 中 国 & フィリピン & タ & 米 国 & 英＼cjkstart国 & ブラジル & ペルー & その他 \\
\hline \multirow{3}{*}{1995 年 } & 総数 & 28 & 13 & 6 & 4 & - & - & - & 4 & - & 1 \\
\hline & 男 & 15 & 10 & 2 & 1 & - & - & - & 2 & - & - \\
\hline & 女 & 13 & 3 & 4 & 3 & - & - & - & 2 & - & 1 \\
\hline \multirow{3}{*}{2000 年 } & 総数 & 13 & 5 & 2 & - & - & - & - & 3 & 2 & 1 \\
\hline & 男 & 8 & 4 & 1 & - & - & - & - & 2 & 1 & - \\
\hline & 女 & 5 & 1 & 1 & - & - & - & - & 1 & 1 & 1 \\
\hline \multirow{3}{*}{2005 年 } & 総数 & 9 & 3 & - & 1 & 1 & - & - & 4 & - & - \\
\hline & 男 & 5 & 2 & - & 1 & 1 & - & - & 1 & - & - \\
\hline & 女 & 4 & 1 & - & - & - & - & - & 3 & - & - \\
\hline \multirow{3}{*}{2009 年 } & 総数 & 9 & - & 1 & - & - & 1 & - & 2 & 2 & 3 \\
\hline & 男 & 6 & - & - & - & - & 1 & - & 1 & 2 & 2 \\
\hline & 女 & 3 & - & 1 & - & - & - & - & 1 & - & 1 \\
\hline \multirow{3}{*}{2016 年 } & 総数 & 7 & - & 2 & - & - & - & - & 5 & - & - \\
\hline & 男 & 6 & - & 2 & - & - & - & - & 4 & - & - \\
\hline & 女 & 1 & - & - & - & - & - & - & 1 & - & - \\
\hline
\end{tabular}

が増加していることや，自治体で外国人児童虐待防止の ための取り組みが始動したことを示す記事もあった。

\section{2）在日外国人の年少人口における不慮の事故による死 亡数の推移}

人口動態統計に打ける，主要死因別年齢調整死亡率の 国籍（日本・外国）別にみた比較（2005 年）では, 全 年齢に打ける不慮の事故死亡率は, 日本人男性 28.9 に 対し外国人男性 32.1, 日本人女性 11.3 に対し外国人女 性 15.3 と, 男女いずれに抢いても外国人で高いことが わかっている。

不慮の事故死亡数には豦待死が含まれる可能性がある ため, 児童虐待による死亡の実態把握に関わる統計資料 の 1 つとて, 不慮の事故による死亡を観察する必要が ある。在日外国人の児童虐待に関する統計は未整備で, 実態把握が困難な現状に括いて, 在日外国人の年少人口 に打不慮の事故による死亡数の推移は, その手がか りとして重要である。在日外国人の国籍（出身地）別・ 死因別・年齢別死亡数に関する統計データは, 人口動態 統計の保管統計表より 1995 年以降のデータが閲覧可能 である。表 2 は, その公表データをもとに著者らが作成 したもので，年少人口に打ける国籍 (出身地) 別・年次 別の不慮の事故による死亡数を示した。2011 年から 2016 年の 5 年間について実数の年次推移は， 3 人， 5 人， 5 人, 2 人, 6 人, 7 人であった。

ところで，行政機関による統計資料には，在日外国人 をひとくくりにした，性別・年齢別・死因別の年齢調整 死亡率は公表されているが, 国籍（出身地）別では公表 されていない。そのため, 日本人と在日外国人の各国籍 (出身地) 別の不慮の事故死亡率を比較するには, 各国 籍 (出身地) 別の性別・年齢別人口と死亡数の双方のデー タを入手して，手作業による算出が必要となる。

\section{4. 在日外国人の親をもつ子どもに発生した 家庭内览童虐待}

日本に打いて，子ぞも虐待の発生数・率を知るための 調査は，2000年に実施された厚生労働科学研究（主任 研究者：小林 登）（2）の調査以降行われていない。在 日外国人を親にもつ子ぞもに限らず，日本で発生した子 ぞも虐待の全体像は十分に把握されていると言えない現 状がある。

本稿では, 平成 22 年度児童関連サービス調査研究等 事業「外国人親をもつ子どもの家庭内被虐待の発生頻度 とその特性に関する横断調査研究」(20)として, 著者 らが実施した受託研究の調査結果の一部を紹介する。な 扔，類似の調査は児相業務としても過去に実施されたこ とがなく, 在日外国人に関する児童虐待の実態を把握す る本邦初の調査となった。この研究計画は, 和歌山県立 医科大学が設置する倫理委員会で度学研究に関する倫理 指針による審査を受けて，その承認を得た後に調査を実 施した。

\section{1）調査概要}

日本全国の児相（調査実施時点で 219 か所）を対象に 2010 年 9 月〜 2011 年 1 月に郵送法による横断調査を実 施した。研究計画説明文書, 調査協力依頼文書, 調査票 を児相所長宛に送付し，下記に定義した一次調査と二次 調査の二段階で自記式質問紙調査を実施した。研究協力 についての判断は児相所長に委初, 同意する場合に回答 を記載して返信用封筒で返送してもらった。

調査対象期間は 2007 年 4 月〜 2010 年 8 月で，どちら か一方もしくは両方の親が外国人であった子どもに発生 した家庭内被虐待例の経験数を調查した (一次調查)。 一次調査の結果で経験数 1 以上であった施設を対象に, 事例調査（被虐待児の性別，出生年月または年齢，親の 
国籍 (出身地), 虐待の種類, 主たる虐待者, 通告経路 を含む）を実施した（二次調査）。

\section{2) 調査結果}

\section{（1）家庭内での虐待事例の発生状況について}

一次調查の有効回答は $74 \%$ で，その $78 \%$ の施設では ぞちらか一方の親が外国人であった家庭に打ける児童虐 待の新規発生例の経験があった。調査対象期間の 3 年 5 か月間に該当事例を経験しなかったと回答した施設は 23 都道府県の 33 施設と政令指定都市の 2 施設であった。 2007 年 4 月からの 3 年 5 か月間に, 122 施設で，少なく とも 1,639 例の事例が経験された。年度別で回答してい なかった事例を除くと，2007 年度は 82 施設で 340 例が 経験され，2008年度は91施設で 376 例が経験され， 2009 年度には 101 施設で 457 例が経験されていた。 2010 年 $4 \sim 8$ 月の 5 か月間では 82 施設に扎いて 261 例 が経験されて扣り，同様の発生状況が続くと仮定すると 2010 年度の新規発生は 626 例が見込まれた。

\section{（2）事例の特徵について}

二次調査で収集された 1,111 例の特徴について図 5 に 要約を示した。被虐待児の男女比（未回答 28 例）は 0.88 であった。年齢（未回答 4 例）は $0 \sim 19$ 歳（中央值 8 , 最頻值 8）で, 乳児は 4.3\% であった。年齢層別にみると, $0 \sim 2$ 歳が $15 \%, 3 \sim 6$ 歳 $24 \%, 7 \sim 12$ 歳 37\%, $13 \sim$ 15 歳 $18 \%$ で, 女児は男児に比べて平均年齢が有意に高 <（男 $7.5 \pm 4.5$ 歳, 女 $8.8 \pm 5.1$ 歳; $P<0.01$ ), 年齢分布 は男女で異なった（図 5A)。図 5Bに示したと打り，虐 待の種類は, 身体的虐待単独 38\%, ネグレクト単独 $33 \%$, 心理的虐待単独 21\%, 性的虐待単独 $6.5 \%$ であった。 性的虐待は 74 例（身体的虐待と複合した 2 例を含む） で認め, 女児で有意に高かった（女 $11 \%$, 男 $2 \% ; P<0.01$ )。 虐待者については，実母の関与を $54 \%$ で認め, 実母 のみは $48 \%$ ，実父母が $6 \%$ であった。虐待への実父の関 与は $40 \%$ で認め, 実父のみは $34 \%$ であった。親カップ ルの国籍（出身地）の組久合わせを図 $5 \mathrm{C}$ に示した。具 体的には，父日本・母フィリピンが全体の $29 \%$ を占め て最多で, 次いで, 父ブラジル・母ブラジルが $9 \%$, 父 日本・母中国が $7 \%$ であった。な拈，親カップルの国籍 （出身地）の組久合わせ（父母外国人，母外国人・父日 本人, 父外国人・母日本人) と, 主な虐待者が実母か実 父かの間には，有意な関連を認めなかった。

（3）巟相への通告経路について

児相への通告経路については，教育機関から $18 \%$, 警察から $18 \%$ ，福禅事務所・女性相談所から $17 \%$, 家族・ 親族から 14\%，近隣から 10\%，市町村から 6\%であった。 な扮，子ども本人からの通告は 19 例（女 16 例，男 3 例） であり, 年齢は $8 \sim 17$ 歳（中学生以上 14 例）で, 虐待 の種類別にみると身体的虐待 8 例, 性的虐待 5 例, ネグ レクト 3 例, 心理的虐待 2 例, 複合（身体的と心理的） 1 例であった。

\section{（4）事例の転帰について}

図 5D に，事例の転帰を示した。終了が $53 \%$ ，継続中 が 36\%であった。なお，管轄外転居の内訳と，関係す る機関間での情報連携の有無については，国内の管轄外 の地域に転居した 68 例中 51 例 $(75 \%)$ で専門機関間の 連携がなされていたのに対して，帰国した 33 例のらち 連携がなされたのは 2 例 $(6 \%)$ であった。

\section{5. 外国人からの坚童福祉に関する相談と わが国の行政サービスにおける言語の課題}

外国人親をもつ子ぞもの支援には，在日外国人の人口 集団打よび家庭内に打称多国籍化・多民族化・多文化 化の現状をふまえて, 国籍 (出身地) 別の人口学的特徵 を踏まえた対応が求められる。母親が外国人の場合，異 文化の中で日本の保健医療福祉システムに関する十分な 知識を持ち合わせず，不自由な日本語で子どもの養育を 担らことになる $(7-11,14)$ 。親の生育歴や，パートナー からのドメスティック・バイオレンスの潜在の可能性, 就労や家庭の社会経済状況など, 複雑な情報の収集と解 釈，配慮が必要である $(12-16,19)$ 。

前述の子ども未来財団平成 22 年度児童関連サービス 調查研究等事業の受託研究 (20) に扣いて実施した全国 の児相を対象とした調査で，外国人からの相談に対応し た経験と用いた言語について対象 219 施設の $72 \%$ にあ たる 157 施設から回答が得られた。そのらちの 17 施設 (11\%) は地域の外国人や外国語に関わる社会資源と組 織間で連携して複数の言語に対応していた。その一方で, 93 施設 (59\%) が外国語への対応に困難を抱えていた。 ここでは, 回答した 157 施設の調査結果を概説する $(20)$ 。 な技，著者らが実施した全国調査の結果を受けて，翌年 には, 子ども未来財団平成 23 年度児童関連サービス調 査研究等事業によって, 児相の職員を対象とした聞き取 り調査をもとに質的研究が実施されており, その詳細は 既報を参照されたい $(28,29)$ 。

\section{1）相談者の国籍（出身地）と母語}

相談者の国籍（出身地）は出現頻度の高い順に，フィ リピン, ブラジル, 中国, ペルー, タイ, 韓国・朝鮮, インドネシアであった。相談者の母語は出現頻度の高い 順に, ポルトガル語, 中国語, タガログ語, スペイン語, 英語, タイ語, ハングルであった。

\section{2）外国人からの相談に対応した際に用いた言語と方法 の類型}

相談者との日常会話によって測られた日本語会話の能 力が，児童相談所が行う相談業務に扣いて用いられる言 語の選択過程に扮いて比較的優先度の高い判断基準と なっていた。相談者の身近に日本語で会話が可能な人物 がいて，相談者側がその人物を同伴して児童相談所を訪 れた場合には，児童福祉の専門機関として児童相談所の 
日衛誌 (Jpn. J. Hyg.) 第 74 巻 2019 年

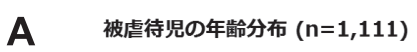

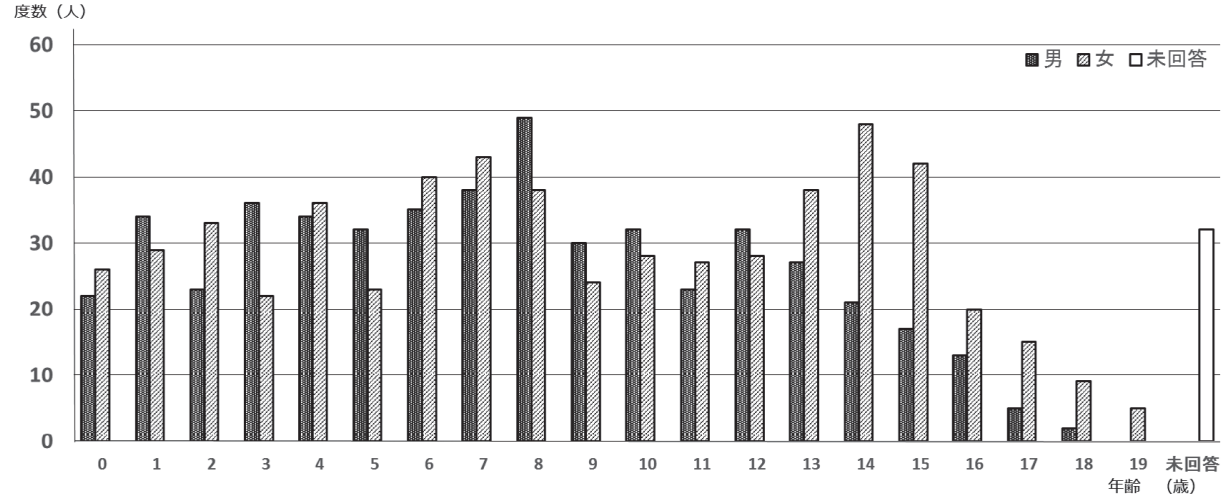

B

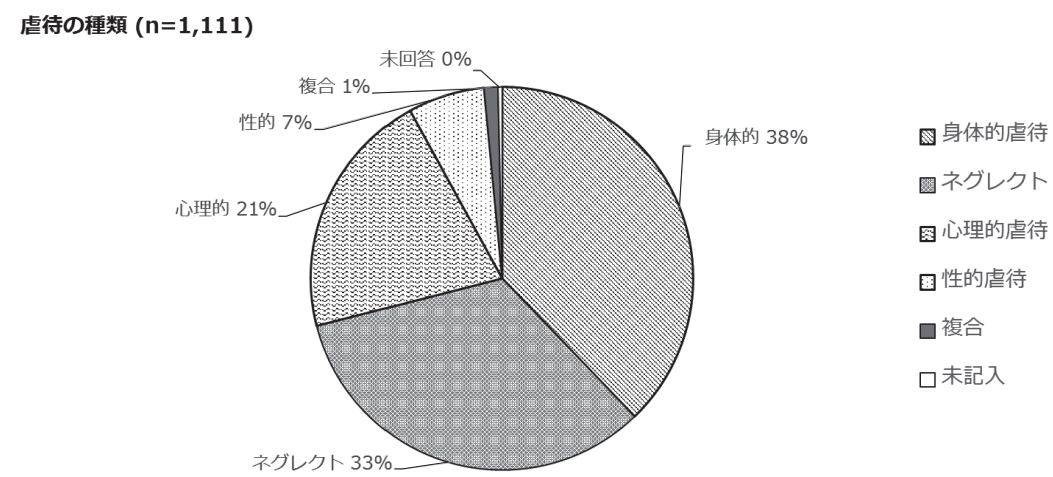

C

親の国籍 (出身地) $(n=1,111)$

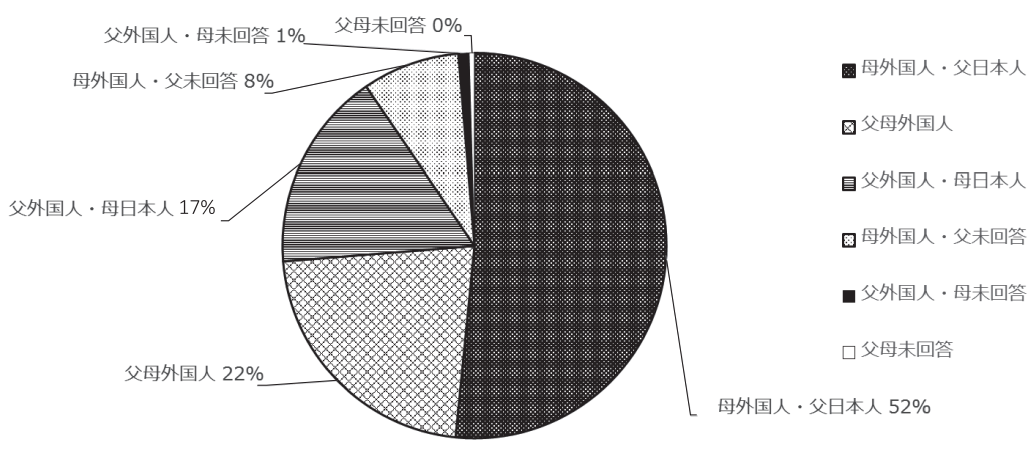

D

転帰 $(n=1,111)$

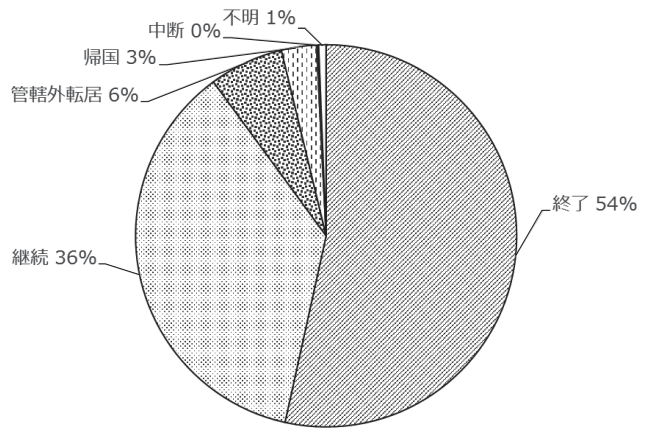
图終了
回継続
国管轄外転居
四帰国
q中断
口不明

図 5 在日外国人の親をもつ子どもに発生した家庭内児童虐待事例の特徵 $(n=1,111)$ (著者らの調查結果から） 
A. 児童相談所側が日本語で対応

1. 相談者と担当者，ともに日本語を使った

1）相談者が日本語で会話が可能だったため

34 施設 $(22 \%)$

2) 相談者が片言の日本語を話したため

28 施設 $(18 \%)$

2. 相談者は外国語，担当者は日本語を使った

1）相談者の家族が通訳の役目

(1) 親の一方が日本人で，相談者と担当者間の通訳の役目

19 施設 $(12 \%)$

（2）子どもが日本語で会話が可能で，相談者（親）と担当者間で通訳の役目

6 施設

2）相談者の同伴者（知り合い，支援団体，他）が通訳の役目

37 施設 $(24 \%)$

B. 児童相談所側が外国語（相談者の母語，相談者が英語を話す場合に英語）で対応

1. 相談者は外国語, 担当者は日本語

1）児童相談所側が通訳を手配

2）市町村関係機関の職員で外国語で会話が可能な者が通訳の役目

32 施設

7 施設

$(20 \%)$

2. 相談者と担当者, ともに外国語

览童相談所職員が外国語で対応

13 施設 $\quad(8 \%)$

担当者が行う相談業務に挍いても，「相談者に同伴した 人物」が通訳の役目を果たしている場合があった。身近 な人物のなかには「相談者の子ども」が含まれていた。 相談者の子どもが，在日外国人である親と児相担当者の 間で子ぞも虐待を含む児童福祉についての相談内容を通 訳する役目を果たしている現実があることがわかった。

表 3 に，外国人からの相談に対応して用いられた言語 と通訳等の対応のパターンを分類し, 回答状沉とともに 示した。外国語対応が可能な体制について 3 類型に分類 された（児童相談所側が通訳者を手配する，市町村関係 機関に勤務している外国語で会話が可能な職員が通訳の 役目をする，児童相談所職員が外国語を使用して相談に 対応する)。

\section{3）相談業務で使用する言語とその体制や工夫}

外国人からの相談に対して現在行っている言語対応の 工夫や体制について，全体の 49\%にあたる 108 施設か ら回答があり，68 施設から具体策が示された。言語の 種類では, 英語が対応可能と回答したのは 33 施設で, 英語以外の言語が対応可能と回答したのは 30 施設（中 国語 19 施設, タイ語 18 施設, ポルトガル語 16 施設, ベトナム語 16 施設, ロシア語 15 施設, タガログ語 14 施設, ハングル 12 施設, 台湾語 12 施設, イタリア語 12 施設, ドイッ語 11 施設, ビザヤ語 11 施設, インド ネシア語 10 施設, フランス語 10 施設, スペイン語 9 施 設）であった。

複数の言語に対応が可能と回答した施設はいずれも, 国際交流協会など地域の社会資源との組織連携によって 対応していた。一方で，外国語での相談への対応が可能 としながらも, 市町村関係機関の職員の個人の言語能力 や無償ボランティアによる通訳を期待する回答も少なく なかった。

\section{6. 在日外国人の人口学的特徵と児童福祉の課題}

本稿では，まず在留外国人統計と人口動態統計を用い て，わが国で暮らす在日外国人の人口動向拉よび婚姻と 出生について, 国籍 (出身地) 別に情報を整理し, 分析 した結果を記述した。在日外国人の国籍（出身地）は多 様化して扣り，国籍（出身地）によって年齢構成，居住 地, 婚姻, 出生の状況には異なる特徵があることを示し た。1980 年代後半以降, 外国人母と日本人父のカップ ルの出生数が, 日本人母と外国人父のカップルの出生数 よりも一貫して多かったが，2007年以降は外国人母と 日本人父のカップルからの出生数が減少に転じ, 2014 年に汇涪同数となって，2016 年では日本人母と外国人 父のカップルからの出生数がやや多かった。在日外国人 の年少人口は約 22 万人で，その国籍（出身地）は中国 やブラジル, 韓国・朝鮮, フィリピン, ベトナム, ペルー, ネパール，インドなど多岐にわたっていた。

次に, 子ども未来財団平成 22 年度児童関連サービス 調査研究等事業 (20) として, 全国の児相を対象として 著者らが実施した調査結果を紹介した。2007 年 4 月か らの 3 年 5 か月間に，少なくとも全国の $58 \%$ の巟相で, どちらか一方もしくは両方の親が外国人であった子ども に発生した家庭内被虐待の事例が経験され，1,639件の 事例が報告された $(20)$ 。二次調査で事例の情報が得ら れた 1,111 例の結果をもとに, 在日外国人を親にもつ子 ぞもの家庭内被虐待に関して疫学的記述を行った (20)。 一方，年間発生数・率を算出するには，調査への有効回 答率の地域間差と母数となる在日外国人の年少人口の地 域間差を考慮する必要があるが，児童相談所の管轄区域 についての情報が入手困難であった（20）。また，在日 外国人を親にもつ子ぞもに発生した児童虐待の場合，市 町村空口で対応困難などの理由で児相が対応する割合が 高いことが予測されるものの市町村空口へ通告されたが 児相が関わらなかった事例についての実態は把握できな 
かった。

在日外国人家庭の児童福祉の相談には, 個別の事情に 応じた臨機応変で的確な対応が要求されている。急速な 国内の国際化に伴って在日外国人の子ぞもの児童福祉相 談には, 国籍 (出身地) 別の人口学的特徵を踏まえた対 応が必要となっている状況が確認された (20,28, 29)。 外国人の親からの児童福祉の相談に対して, 多くの児相 で職員の個人的な努力により対応の工夫がなされてい た。組織的に取り組んでいる児相の先進的な活動 (30, 31）を調查し分析することによって一般化可能な要素を 抽出し，それぞれの地域に抢いて児相や市町村の空口で の対応に役立つ具体的な方略を提案する必要に迫られて いる。改善の必要がある事例として, 子どもに通訳の役 割を担わせていたものが相当数あることが確認され (20), 子どもの権利と国際的な視点から速やかに改善す べきである。また，相談者に同伴した者に通訳の役割を 担わせて相談場面に同席させることも (20), 相談内容 の性質上望ましくない方法である。相談業務の基本を理 解して継続的に関わる必要性と相談者の母語を用いて相 談に応じる重要性を鑑みた場合に, 日本と相談者の出身 の国 (地域) の双方の児童福祉制度と文化に習熟した通 訳体制の整備が望まれる $(29,32)$ 。

児童虐待への対応の予防施策の効果的な実施には，実 態把握のためのモニタリングとその情報の分析による評 価と見直しが欠かせないが, 在日外国人の人口学的特徵 とその家庭に発生した児童虐待について学術研究は不足 している。今後, 人口学的特徵と児童福祉の課題に対し て, 複数の学問領域の学術成果の融合や分野横断的な研 究手法の開発による学際的探求が益々必要とされて扣 り, 日本衛生学会とその会員による学術面の寄与が期待 される。

\section{謝辞}

本稿の執筆にあたり，こども未来財団 平成 22 年度 児童関連サービス調査研究等事業「外国人親をもつ子ど もの家庭内被虐待の発生頻度とその特性に関する横断調 查研究」(主任研究者：北野尚美）の受託研究として実 施した調査結果の一部を用いた。

利益相反なし

\section{文献}

（1）厚生労働省. 平成 29 年度の児童相談所での児童虐 待相談対応件数. https://www.mhlw.go.jp/stf/houdou/ 0000173365_00001.html (2018.11.30)

（2）小林 登. 厚生科学研究（2001 年子ども家庭総合研 究事業）児童虐待および対策の実態把握に関する総合 的研究 (主任研究者: 小林登) 平成 13 年度研究報告書, 2004.

（3）北野尚美, 柳川敏彦, 小池通夫, 吉川徳茂. 和歌山県
下の家庭内児童虐待の悉皆調査成績. 和歌山医学 2003;54:171-177.

（4）厚生労働省．子ども虐待による死亡事例等の検証に ついて. https://www.mhlw.go.jp/stf/seisakunitsuite/bunya/ 0000198645.html (2018.11.30)

（5）厚生労働省. 健やか親子 21 (第 2 次）ホームページ. http://sukoyaka21.jp/about (2018.11.30)

（6）足立安正，上野昌江．市町村に打ける妊娠届出時の情 報把握に関する実態調査. 兵庫医療大学紀要 2018;6: $1-9$.

( 7 ) Hotta M, Ali M, Ushijima H, Lee S, Nakamura Y, Shigeta M, et al. Situational analysis of maternal and child health services for foreign residents in Japan. Pediatr Int 2007;49: 293-300.

（8）李 節子，今泉 恵，澤田貴志. 在日外国人母子支援 ガイドライン一地域母子保健実践活動の分析と提言 から. 助産雑誌 2003;57:680-688.

（9）橋本秀実，深堀浩樹，伊藤 薰，馬場雄司，山路由実 子，佐々木由香，他. 三重県保健師の在日外国人への 保健活動. 三重県立看護大学紀要 2010;14:19-26.

（10）伊藤美保, 中村安秀, 小林敦子. 在日外国人の母子保 健に打汀通訳の役割. 小児保健研究 2004;63:249255.

（11）中村安秀，北野尚美. 子ぞも虐待の国際比較. 小児内 科 2010;42:1754-1758.

(12）李 節子, 日暮 眞. オーバースティ外国人妊産婦お よび児童の母子保健・福祉に関する研究—全国福祉事 務所に打ける実態調査結果の分析より一. 日本公衆衛 生雑誌 1996;43:315-324.

（13）金 愛慶，津田友理香. 日本に打汀国際結婚家庭に 関する心理社会的支援：在日フィリピン人の DV 被害 者支援についての一考察. 名古屋学院大学論集社会科 学篇 2015;51:95-104.

（14）武田真由美. A 県に括郆る在日外国人の子育て二ーズ に関寸る探索的研究: 在日外国人保護者, 行政担当者, 支援者へのインタビュー調査より. 関西学院大学社会 学部紀要 2007;103:115-127.

（15）李 節子，日暮 眞. 全国福祉事務所に括ける在日外 国人妊産婦扣よび児童の実態調査一外国人相談ケ一 スの対応状況一. 日本公衆衛生雑誌 1996;43:486-496.

（16）馬場幸子. 米国 Latino 移民と社会的養護下にいる Latino の子ぞもへの支援の現状と課題一日本に打ける 在日外国人への児童福祉サービス体制改善への示唆 一. 子どもの虐待とネグレクト 2012;14:195-202.

（17）独立行政法人統計センター. e-Stat 政府統計の総合空 口. https://www.e-stat.go.jp (2018.7.31)

(18) Koumura M. Global health and Japan's foreign policy. Lancet 2007;370:1983-1984.

（19）荒牧重人, 榎井 縁, 江原裕美, 小島祥美, 志水宏吉, 南野奈津子, 他 (編). 外国人の子ぞも白書一権利・ 貧困・教育・文化・国籍と共生の視点から一。東京： 明石書店, 2017 .

（20）北野尚美, 李 錦純, 中村安秀, 柳川敏彦, 竹下達也. 平成 22 年度児童関連サービス調査研究等事業. 外国 人親をもつ子どもの家庭内被虐待の発生頻度とその 特性に関する横断調査研究 (主任研究者: 北野尚美). こども未来財団受託研究報告書. 2011.3. 
（21）財団法人入管協会. 在留外国人統計昭和 34 年版～平 成 29 年度版. 東京 : 財団法人入管協会.

（22）厚生労働省大臣官房統計情報部（編）. 昭和 30 年～平 成 28 年人口動態統計上・中 -下巻. 東京 : 財団法人 厚生統計協会.

（23）厚生労働省大臣官房統計情報部（編）。平成 15 年度・ 日本に打ける人口動態一外国人を含む人口動態統計 一人口動態統計特殊報告. 東京 : 財団法人厚生統計協 会, 2003 .

（24）厚生労働省大臣官房統計情報部 (編). 平成 19 年度 日本に打ける人口動態一外国人を含む人口動態統計 一人口動態統計特殊報告. 東京 : 財団法人厚生統計協 会, 2008 .

（25）法務省．在留外国人統計（旧登録外国人統計）統計表. http://www.moj.go.jp/housei/toukei/toukei_ichiran touroku.html (2018.7.31)

（26）総務省統計局. 人口推計平成 29 年 11 月報. http:// www.stat.go.jp/data/jinsui/pdf/201711.pdf (2018.7.31)

（27）厚生労働省. 人口動態統計別表. 日本に打汀る外国人. 出生, 出生数, 母の平均年齢; 母の国籍・母の年齢 $(5$ 歳階級) 別, 2016 (2018 年公開) 独立行政法人統計 センター：e-Stat 政府統計の総合空口. 人口動態調査 人口動態統計 確定数. 別表 5 , 出生数, 母の平均年
齢 ; 母の国籍・母の年齢（5 歳階級）別. https://www. e-stat.go.jp/dbview?sid=0003216841 (2018.7.31)

（28）馬場幸子，北野尚美，Lisette Piedra，李 錦純，中村 安秀. 子ぞも虐待ケースの多文化多言語に配慮した支 援のあり方に関する質的調査研究一在日外国人への 家庭児童相談機関の対応を中心に一。こども未来財団 平成 23 年度児童関連サービス調査研究等事業（主任 研究者：馬場幸子), 2012.3.

（29）馬場幸子，北野尚美，李 錦純. 児童相談所に打忷る 多言語対応の現状と通訳利用時の課題一児童相談所 職員への聞き取り調査の質的分析一。 子ぞもの虐待と ネグレクト 2013;15:173-181.

（30）公益財団法人かながわ国際交流財団. 外国人ママが日 本で安心して出産するために〜母子保健にかかわる皆 さんへ〜. http://www.kifjp.org/wp/wp-content/uploads/ 2016/04/iryou_6page.pdf (2018.7.31)

（31）公益財団法人京都府国際センタ一．外国籍府民の方 へ. https://www.kpic.or.jp/njfumin/mobile.html (2018. 7.31)

（32）植村直子，マルティネス真喜子，畑下博世. 在日ブラ ジル人妊産婦の日常生活と保健医療ニーズ 妊婦健 診・家庭訪問でのフィールドワークより。日本公衆衛 生雑誌 2012;59:762-770. 